\title{
ПРАВО НА ЗАХИСТ ПЕРСОНАЛЬНИХ І ГЕНЕТИЧНИХ ДАНИХ - ОДИН ІЗ АСПЕКТІВ ПРАВОВОГО СТАТУСУ ДОНОРА ЯК СУБ'СКТА ВІДНОСИН ЗІ СТВОРЕННЯ ТА ВИКОРИСТАННЯ БІОБАНКУ
}

Постановка проблеми. Надзвичайно важливим та таким, що виникає в усіх донорів незалежно від виду донорства є, зокрема, забезпечення принципу анонімності, який реалізується через право донора на забезпечення конфіденційності інформації про нього та право на захист його персональних даних. При цьому захист персональних та генетичних даних є особливо актуальним у контексті діяльності щодо збирання та використання людських біологічних матеріалів та пов'язаних із ними персональних даних осіб, що передають свої біологічні матеріали до складу біобанків. Сьогодні дане питання є малодослідженим в Україні, де наукові розвідки більше скеровані в русло аналізу захисту персональних даних у сфері охорони здоров'я загалом. Натомість у Європейській та світовій доктрині цьому питанню присвячено чимало досліджень, а законодавство постійно вдосконалюється з метою охорони персональних даних у тому числі у сфері створення та використання біобанків. Особлива актуальність даної проблематики також зумовлюється активним розвитком діяльності щодо створення та використання біобанків в Україні та відсутністю її спеціального правового регулювання.

Аналіз останніх досліджень. Дослідженню проблематики захисту персональних даних у сфері діяльності щодо створення та використання біобанків в українській доктрині наразі не приділено достатньої уваги. У літературі можна лише знайти роботи, присвячені загальним питанням правового регулювання створення і використання біобанків чи окремим аспектам цієї діяльності, зокрема праці Р.Ю. Гревцової, О.Ю. Кашинцевої, І.Я. Сенюти та ін., присутні також дослідження, присвячені загалом захисту персональних даних в адміністративно-правовому аспекті, зокрема дисертації Тунік А.В., Обуховської Т.І., конституційно правові дослідження захисту інформації про особу, а саме робота Кожан А.В., а також робота Чабан O.A., у якій досліджено особисте немайнове право фізичної особи на таємницю про стан здоров'я з точки зору цивільного права.

Мета дослідження. Тому в даній статті ми проаналізуємо особливості правового регулювання захисту персональних даних донорів як суб'єктів, що передають свої біологічні матеріали та пов'язані з ними персональні дані до складу біобанків в Україні, визначимо проблемні питання, що можуть виникати у цій сфері та запропонуємо ймовірні шляхи для їх вирішення.

Виклад основного матеріалу. У першу чергу необхідно визначити, яким чином українське законодавство забезпечує конфіденційність інформації про донора та здійснює охорону його персональних даних у сфері створення та використання біобанків.

Поняття «персональні дані» визначено у ст. 2 Закону України «Про захист персональних даних» [1] та у ст. 11 Закону України «Про інформацію» [2] як відомості 
або сукупність відомостей про фізичну особу, яка ідентифікована або може бути конкретно ідентифікована. Крім того, в Законі про інформацію також використовується поняття «конфіденційна інформація», яке визначене у ст. 7 Закону України «Про доступ до публічної інформації» [3] як інформація, доступ до якої нею обмежено особою, якій ця інформація належить та яка може поширюватися у визначеному особою порядку виключно за ії бажанням відповідно до передбачених нею умов. Дані про національність, освіту, сімейний стан, релігійні переконання, стан здоров'я, а також адреса, дата і місце народження у ч. 2 ст. 11 Закону України «Про інформацію» віднесено до конфіденційної інформації про фізичну особу.

Активний розвиток та постійне збільшення кількості біобанків у світі також сприяє створенню спільних регіональних та світових баз даних, що входять до складу біобанків та містять персональні дані донорів. Створюються також і бази даних біобанків, які мають відкритий доступ, що має на меті, по-перше, створити умови для розвитку науки та полегшити доступ для науковців до певного виду даних, які можуть ними використовуватися, а також покращення доступу до донорського матеріалу з метою трансплантації. Водночас розміщення у відкритих базах даних персональних даних донорів, зокрема медичної, а також генетичної інформації, зберігаючи конфіденційність даних, що дозволяють прямо ідентифікувати особу (ім'я, адреса тощо) шляхом їх знеособлення, що відбувається лише після дозволу суб'єкта даних на таке розміщення. Та навіть якщо конфіденційні дані в даному випадку належно захищені, генетичні дані все ж можуть допомогти недобросовісним учасникам даних відносин відслідкувати носія інформації, а несанкціоноване використання генетичних даних може завдати шкоди особі, якій ці генетичні дані належать.

Генетичні дані мають особливий статус, оскільки вони дають змогу з досить високою вірогідністю передбачити майбутній стан здоров'я людини, здорової на момент обстеження, і тому можуть бути використані для утиску її прав і як підстава для дискримінації під час використання третіми сторонами. Під час отримання і використання генетичної інформації виникає небезпека порушення права знати чи не знати інформацію про себе, права на самостійне рішення щодо свого здоров'я і репродукції, права на конфіденційність, права родичів пацієнта на генетичну інформацією для прийняття власного рішення про необхідність тестування [4]. «Існування у клітинах організмів таких сукупностей генів, які зберігають відомості про послідовність процесів обміну речовин у періоди росту та розмноження, про склад, будову і функції білків та нуклеїнових кислот - це генетична інформація» [5]. Генетична інформація мітить дані про минуле людини, їі біологічну спадщину з т.з. індивідуальної сімейної історії походження [6].

Наприклад, у Європі зараз є дуже популярною та активно рекламується в Масмедіа послуга щодо отримання інформації про своє походження шляхом надання власної ДНК для її аналізу. Таким чином, суб'єкт, що збирає та аналізує такий біологічний матеріал, отримує доступ до генетичних даних великої кількості осіб на підставі їх дозволу, а отже, збирає та зберігає таку особливо чутливу інформацію. Тому ми можемо зробити висновок, що людські біологічні матеріали, що зберігаються в біобанках, та пов'язана з ними інформація включає в себе не лише 
біологічні, а й біографічні дані, і тому несанкціоноване користування генетичними даними несе масу ризиків як для кожного окремого члена суспільства, так і для певних його груп чи людства в цілому.

Право кожного на захист своїх персональних даних та обмеження можливостей їх використання метою, встановленою наданим особою дозволом, закріплене, зокрема, у ст. 8 Хартії основних прав Європейського Союзу. Також важливу роль у регулюванні даного питання відіграє Регламент 2016/679 Європейського Парламенту і Ради від 27 квітня 2016 року «Про захист фізичних осіб стосовно оброблення персональних даних та про вільне переміщення таких даних, а також про скасування Директиви 95/46/СС» (далі - Регламент) [7], який набрав чинності 3 25.05.2018 р. Особливість та важливість даного акта полягає в тому, що він є універсальним документом, обов'язковим до застосування усіма країнами-членами ЄС. Регламент містить керівні засади для процесу оброблення персональних даних фізичних осіб із метою уникнення чи мінімізації загроз порушення приватності особи. Особливий наголос у Регламенті зроблено на необхідності забезпечення охорони генетичної інформації, яка вважається невід'ємною складовою частиною системи персональних даних особи.

Поняття генетичних даних визначене в п. 34 Регламенту як персональні дані особи, що стосуються її спадкових чи набутих генетичних характеристик та випливають із аналізу біологічного зразка фізичної особи. Важливим також є положення п. 53 Регламенту, яке, зокрема, наголошує на особливій чутливості спеціальних категорій персональних даних, які, відповідно, вимагають більшого захисту та можуть підлягати обробленню виключно для медичних потреб, а також в інтересах носіїв цих даних чи суспільства в цілому, при цьому держави-члени відповідно до ч. 4 ст. 9 Регламенту зобов'язані забезпечувати дотримання наявних та/або запроваджувати додаткові умови, в тому числі обмеження щодо оброблення генетичних даних, біометричних даних чи даних про здоров'я.

Також Регламент закріплює основні принципи, яких потрібно дотримуватися під час оброблення персональних даних, зокрема ст. 5 передбачає законність, справедливість та прозорість; ч. 1 ст. 9 встановлює загальне правило про заборону оброблення персональних даних, у тому числі генетичних, винятки із якого встановлює ч. 2 ст. 9, а саме: за наявності згоди суб'єкта даних на оброблення цих персональних даних для однієї чи декількох передбачених цілей, крім випадків, коли законодавство ЄС чи країни-члена ЄС передбачає, що заборона, передбачена у ч. 1 , не може бути скасована суб'єктом даних; оброблення є необхідним для захисту життєвих інтересів суб'єкта даних чи іншої фізичної особи, якщо суб'єкт даних фізично чи юридично неспроможний надати свою згоду; метою оброблення даних є задоволення суспільних інтересів у сфері громадського здоров'я, таких як захист від серйозних транскордонних загроз здоров'ю та забезпечення високих стандартів якості і безпечності медичних послуг, лікарських препаратів, медичних пристроїв, на основі законодавства ЄС чи законодавства країни-члена, яке передбачає належні і конкретні заходи щодо захисту прав і свобод суб'єкта даних, зокрема професійну таємницю; оброблення необхідне для архівних цілей, в інтересах суспільства, наукових чи історичних дослідницьких цілей чи для цілей статистики відповідно 
до ст. 89 на основі законодавства ЄС чи законодавства країни-члена, яка повинна бути пропорційною до переслідуваної мети, поважати суть права на захист даних і забезпечити належні і конкретні заходи з метою захисту основних прав та інтересів суб'єкта даних.

Отже, норми аналізованого Регламенту формують чіткі правові рамки допустимості використання та оброблення персональних даних фізичних осіб із наголосом на генетичні дані як особливо чутливу складову частину, недоторканність та конфіденційність якої повинна гарантуватися нормами як національного, так і міжнародного законодавства. Це має особливо важливе значення для сфери охорони персональних даних донорів та осіб, біологічні зразки яких входять до складу біобанків, оскільки кожен, навіть найменший біологічний матеріал, до прикладу клітина, містить у собі генетичну інформацію про особу, від якої він був взятий, і навіть якщо інформація про таку фізичну особу була анонімізована, за умови наявності бажання завдяки ДНК-коду можна віднайти донора. Отже, сучасний рівень біомедицини фактично унеможливлює повну анонімізацію особи донора, а отже, забезпечення абсолютної конфіденційності є неможливим. Саме тому законодавець повинен створити дуже вузькі рамки та умови для оброблення таких даних та запровадити державний контроль та нагляд за такою діяльністю, щоб забезпечити найвищий рівень охорони як на національному, так і на міжнародному рівні.

Цікавою з точки зору дослідження генетичних даних є норма ст. 29 (Збереження генофонду народу України) Основ законодавства України про охорону здоров'я [8], яка встановлює, що з метою збереження генофонду народу України, запобігання демографічній кризі, забезпечення здоров'я майбутніх поколінь і профілактики спадкових захворювань держава здійснює комплекс заходів, спрямованих на усунення факторів, що шкідливо впливають на генетичний апарат людини, а також створює систему державного генетичного моніторингу, організовує медико-генетичну допомогу населенню, сприяє збагаченню і поширенню наукових знань у сфері генетики і демографії. А частина друга цієї статті встановлює заборону медичного втручання, яке може викликати розлад генетичного апарату людини. Отже, дана норма закріплює можливість проведення так званого державного генетичного моніторингу та сприяння розвитку генетики як науки, водночас не наголошуючи на створенні державних гарантій охорони генетичних даних кожної окремої особи та недопустимості використання генетичної інформації без письмової поінформованої згоди її носія, що, безумовно, є значним недоліком.

Та все ж не можна виключати можливості виникнення ситуації, коли потреба в забезпеченні суспільного інтересу чи досягнення медичних цілей в інтересах значної кількості людей чи суспільства загалом буде настільки гострою, що оброблення конкретних генетичних даних стане єдиним шляхом до порятунку. I тут варто звернути увагу на положення п. 4 Регламенту 2016/679, яке передбачає, що право на захист персональних даних не є абсолютним правом і має розглядатися з урахуванням його функцій та бути збалансованим з іншими правами. Зокрема, вітчизняні науковці також наголошують на необхідності забезпечення законодавством балансу між забезпеченням принципу відкритості науки та необхідністю захисту персональних даних донорів у діяльності щодо створення та використання біобан- 
ків в Україні. А саме в контексті діяльності щодо створення та використання біобанків це право необхідно збалансовувати з метою та призначенням медицини як науки і як особливої сфери практики, виходячи з її завдань та ролі у суспільстві [9].

Тож які конкретні механізми захисту персональних даних діють сьогодні в національному законодавстві України? Закон України «Про застосування трансплантації анатомічних матеріалів людині» [10], зокрема ст. 11, регулює питання створення та функціонування Єдиної державної інформаційної системи трансплантації (далі - ЄДІСТ), яка створюється з метою інформаційного забезпечення надання медичної допомоги із застосуванням трансплантації та здійснення діяльності, пов'язаної із трансплантацією, та містить визначений цією статтею набір мінімальних даних - відомостей, що є інформацією з обмеженим доступом про донорів, реципієнтів, характеристику анатомічних матеріалів, які збираються, обробляються та захищаються у визначеному законом порядку. До неї включено законом 9 реєстрів: 1) реєстр волевиявлення особи про надання згоди або незгоди на посмертне донорство або призначення нею повноважного представника; 2) реєстр волевиявлення особи, яка надала у встановленому цим Законом порядку згоду на вилучення анатомічних матеріалів для трансплантації та/або виготовлення біоімплантатів із тіла померлої особи, яку вона представляє; 3) реєстр анатомічних матеріалів людини, призначених для трансплантації та/або виготовлення біоімплантатів; 4) реєстр живих донорів; 5) реєстр живих донорів гемопоетичних стовбурових клітин; 6) реєстр реципієнтів; 7) реєстр осіб із трансплантованим анатомічним матеріалом; 8) реєстр закладів охорони здоров'я, що надають медичну допомогу із застосуванням трансплантації та/або здійснюють діяльність, пов'язану із трансплантацією, та інших суб'єктів господарювання, що здійснюють діяльність, пов'язану із трансплантацією; 9) реєстр трансплант-координаторів.

У контексті питання про захист персональних даних донорів важливе значення мають дані, що містяться в перших п'ятьох реєстрах, оскільки саме вони містять інформацію про донорів, конфіденційність якої повинна бути забезпечена нормативними гарантіями.

Зокрема, ч. 5 ст. 11 передбачає, що персональні дані, збирання, зберігання, використання яких не передбачено цим Законом, а також іншими законами, що регулюють суспільні відносини у сфері охорони здоров'я та містять вимоги щодо оброблення персональних даних в інших інформаційно-телекомунікаційних системах, та які одночасно є конфіденційною інформацією про фізичну особу, можуть оброблятися в базах даних ЄДІСТ лише за згодою суб'єктів персональних даних. А ч. 6 ст. 11 встановлює, що оброблення персональних даних, що є конфіденційною інформацією про фізичних осіб, які містяться у ЄДІСТ, здійснюється з дотриманням вимог Конституції України, Законів України «Про захист персональних даних», "Про інформацію» та інших законів. Також ч. 7 ст. 11 встановлює строк зберігання такої інформації, а саме передбачає, що персональні дані про особу, передбачені цим Законом, зберігаються у ЄДІСТ протягом 30 років із дня надходження, крім випадків, коли ці дані виключаються з ЄДІСТ раніше встановленого строку, протягом 30 днів в разі: 1 ) особистого бажання особи (на підставі письмової заяви установленого зразка); 2) смерті (на підставі свідоцтва про смерть): реципі- 
єнта; живого донора; особи, яка надала згоду або незгоду на посмертне донорство або призначила повноважного представника; особи із трансплантованим анатомічним матеріалом; 3) настання таких змін у стані здоров'я реципієнта, за яких він не потребує або йому не може бути проведено трансплантацію, або у стані здоров'я живого донора, за яких він не може виконувати функцію донора анатомічних матеріалів (на підставі відповідної медичної документації); 4) оформлення особою постійного місця проживання за кордоном (на підставі відповідних документів, що підтверджують постійне місце проживання особи за кордоном).

Також закон у ч. 8 ст. 11 визначає вузьке коло суб'єктів, які мають право вносити дані до ЄДІСТ, а саме трансплант-координатори та посадові особи центрального органу виконавчої влади, що реалізує державну політику у сфері надання медичної допомоги із застосуванням трансплантації та здійснення діяльності, пов'язаної з трансплантацією, уповноваженими відповідно до їхніх посадових обов'язків на внесення передбачених цим Законом відомостей до Єдиної державної інформаційної системи трансплантації. Ті ж самі суб'єкти є уповноваженими у ч. 9 ст.11 на доступ до конфіденційної інформації про фізичну особу, що міститься у Єдиній державній інформаційній системі трансплантації. Проте коло суб’єктів із доступом до цієї інформації з певними обмеженнями розширене, оскільки ця ж частина також дозволяє судово-медичним експертам доступ до конфіденційної інформації про фізичну особу, але лише ту, що міститься в реєстрі волевиявлення особи про надання згоди або незгоди на посмертне донорство або призначення нею повноважного представника та в реєстрі волевиявлення особи, яка надала у встановленому цим Законом порядку згоду на вилучення анатомічних матеріалів для трансплантації та/або виготовлення біоімплантатів із тіла померлої особи, яку вона представляє. Крім того, в редакції від 28.02.2019 року коло уповноважених осіб було розширене, і до вищезазначених законодавець додав також лікарів загальної практики сімейних лікарів, але лише щодо внесення відомостей до реєстру надання згоди або незгоди на посмертне донорство або призначення повноважного представника.

Ще однією гарантією охорони персональних даних є передбачене у ч. 10 ст. 11 закону здійснення у ЄДІСТ персоналізації та фіксації кожного окремого випадку доступу до неї осіб, визначених цим законом (доступу до самих реєстрів та доступу до електронних карток зареєстрованих у реєстрах фізичних осіб). I тут варто наголосити, що в електронній картці зареєстрованої в реєстрі фізичної особи відображатиметься прізвище, ім'я, по батькові осіб, які вносили до неї передбачену цим Законом інформацію, а також осіб, які ознайомлювалися з наявною у цій електронній картці інформацією, дата і час внесення відповідних даних та їх перегляду, що дасть змогу відслідковувати всю історію роботи з персональними даними та за потреби ідентифікувати порушників.

Вартою уваги є також ч.12 та ч. 13 ст. 11, які не лише декларують захист від несанкціонованого втручання в роботу системи, але й визначають перелік конкретних порушень, які тягнутимуть за собою відповідальність. Зокрема, ч. 13 ст. 11 встановлюе, що особи, винні в порушенні правового режиму конфіденційної інформації (збирання, реєстрація, накопичення, зберігання, оброблення, адаптування, зміна, поновлення, використання і поширення (розповсюдження, реа- 
лізація, передача), знеособлення, знищення), несвоєчасності внесення, подання недостовірної інформації, свідомому приховуванні відомостей, що містяться в Єдиній державній інформаційній системі трансплантації, несуть відповідальність згідно із законом.

Отже, конфіденційна інформація, що міститиметься у цих реєстрах та у системі, одночасно вважатиметься інформацією з обмеженим доступом, як це передбачено у ч. 1 ст. 6 Закону України «Про доступ до публічної інформації». Варто також зауважити, що норми Закону «Про застосування трансплантації анатомічних матеріалів людині», які стосуються охорони персональних даних, що міститимуться у вищезазначених реєстрах, стосуються лише правового статусу донорів, які надають свої біологічні матеріали для трансплантації та/або виготовлення біоімплантатів і не стосуватимуться інших суб’єктів, біологічні матеріали яких можуть входити до складу біобанків, до прикладу для власних чи для дослідницьких потреб. Для регулювання цих відносин діятимуть загальні норми Закону України «Про захист персональних даних».

Проводячи паралель із аналізованим вище новим Регламентом ЄС 2016/679, можна констатувати прогресивність норм Закону України «Про захист персональних даних». Зокрема, ст. 7 (Особливі вимоги до оброблення персональних даних) встановлює заборону оброблення персональних даних про расове або етнічне походження, а також даних, що стосуються здоров'я, статевого життя, біометричних або генетичних даних, за винятком випадків, передбачених ч. 2 цієї ж статті, а саме якщо оброблення персональних даних: 1) здійснюється за умови надання суб'єктом персональних даних однозначної згоди на оброблення таких даних; 2) необхідне для здійснення прав та виконання обов'язків володільця у сфері трудових правовідносин відповідно до закону із забезпеченням відповідного захисту; 3) необхідне для захисту життєво важливих інтересів суб'єкта персональних даних або іншої особи в разі недієздатності або обмеження цивільної дієздатності суб'єкта персональних даних; 5) необхідне для обгрунтування, задоволення або захисту правової вимоги; 6) необхідне в цілях охорони здоров’я, встановлення медичного діагнозу, для забезпечення піклування чи лікування або надання медичних послуг, функціонування електронної системи охорони здоров'я за умови, що такі дані обробляються медичним працівником або іншою особою закладу охорони здоров'я чи фізичною особою-підприємцем, якаодержалаліцензіюнапровадження господарськоїдіяльності з медичної практики, та її працівниками, на яких покладено обов'язки щодо забезпечення захисту персональних даних та на яких поширюється дія законодавства про лікарську таємницю, працівниками центрального органу виконавчої влади, що реалізує державну політику у сфері державних фінансових гарантій медичного обслуговування населення, на яких покладено обов'язки щодо забезпечення захисту персональних даних; 7) стосується вироків суду, виконання завдань оперативно-розшукової чи контррозвідувальної діяльності, боротьби з тероризмом та здійснюється державним органом в межах його повноважень, визначених законом; 8) стосується даних, які були явно оприлюднені суб'єктом персональних даних.

Тобто, як видно із процитованої норми, положення Закону майже ідентичні до положень Регламенту ЄС, тобто відповідають європейським стандартам. Важливою 
є також норма ст. 8 Закону, яка у ч. 1 встановлює невід’ємність та непорушність особистих немайнових прав кожної фізичної особи на персональні дані, а у ч. 2 дає вичерпний перелік прав суб'єкта персональних даних, до яких віднесено: 1) знати про джерела збирання, місцезнаходження своїх персональних даних, мету їх оброблення, місцезнаходження або місце проживання (перебування) володільця чи розпорядника персональних даних або дати відповідне доручення щодо отримання цієї інформації уповноваженим ним особам, крім випадків, встановлених законом; 2) отримувати інформацію про умови надання доступу до персональних даних, зокрема інформацію про третіх осіб, яким передаються його персональні дані; 3) на доступ до своїх персональних даних; 4) отримувати не пізніш як за тридцять календарних днів із дня надходження запиту, крім випадків, передбачених законом, відповідь про те, чи обробляються його персональні дані, а також отримувати зміст таких персональних даних; 5) пред’являти вмотивовану вимогу володільцю персональних даних із запереченням проти оброблення своїх персональних даних; 6) пред'являти вмотивовану вимогу щодо зміни або знищення своїх персональних даних будь-яким володільцем та розпорядником персональних даних, якщо ці дані обробляються незаконно чи є недостовірними; 7) на захист своїх персональних даних від незаконного оброблення та випадкової втрати, знищення, пошкодження у зв'язку з умисним приховуванням, ненаданням чи несвоєчасним їх наданням, а також на захист від надання відомостей, що є недостовірними чи ганьблять честь, гідність та ділову репутацію фізичної особи; 8) звертатися зі скаргами на оброблення своїх персональних даних до Уповноваженого або до суду; 9) застосовувати засоби правового захисту в разі порушення законодавства про захист персональних даних; 10) вносити застереження стосовно обмеження права на оброблення своїх персональних даних під час надання згоди; 11) відкликати згоду на оброблення персональних даних; 12) знати механізм автоматичного оброблення персональних даних; 13) на захист від автоматизованого рішення, яке має для нього правові наслідки.

Усі вищеперелічені права суб'єкта персональних даних стосуються також і суб'єктів, які передають свої біологічні матеріали до складу біобанків. Проте необхідно також мати на увазі, що в деяких випадках під час передачі до біобанків біологічних матеріалів та інформації про особу, від якої вони походять, управитель біобанку може застосовувати анонімізацію (знеособлення) таких даних, що трактується ст. 2 цього ж закону як вилучення відомостей, які дають змогу прямо чи опосередковано ідентифікувати особу, що виключає можливість ідентифікації особи, а отже, дає змогу констатувати відсутність об'єкта охорони - персональних даних. Тому у випадку правомірного знеособлення персональних даних особи управителем біобанку ми можемо говорити про виключення таких відносин зі сфери регулювання законодавства про захист персональних даних. Проте ключовою тут є власне правомірність такого знеособлення. Оскільки знеособлення персональних даних, як і їх знищення, відноситься до різновидів їх оброблення, то такі дії мають здійснюватися лише з дозволу суб'єкта персональних даних із попереднім роз'ясненням наслідків таких дій.

На жаль, на відміну від Європейського Регламенту, український закон передбачає лише можливість знеособлення персональних даних, яке можна прирівняти 
з європейською анонімізацією, яка виключає можливість у майбутньому ідентифікувати суб'єкта персональних даних. Проте, крім анонімізації, існує також так звана псевдонімізація, яку також називають кодуванням. Варто наголосити, що новий Регламент, на відміну від попередніх європейських актів, трактує закодовані, тобто псевдонімізовані дані також як персональні дані, які існують у зашифрованому стані, оскільки за наявності можливості розшифрування, особа все ж може бути ідентифікована, а отже, оброблення таких даних входить до сфери дії законодавства про захист персональних даних. I власне в переважній більшості біобанків персональні дані про особу, від якої походить біологічний матеріал, містяться у закодованому, а не в анонімізованому (знеособленому) стані.

Висновки. Проведений аналіз дав змогу зробити висновок про необхідність спеціального правового регулювання охорони персональних даних особи, пов'язаних зі її здоров’ям, у тому числі генетичних даних у контексті відносин щодо створення та використання біобанків та формування спільних баз таких даних в Україні. Необхідно також встановити законодавчі вимоги щодо передачі таких даних, щодо форми та змісту згоди особи та правових наслідків порушення таких вимог.

Також із метою уникнення неправильного розуміння поняття знеособлення персональних даних та розмежування його із псевдонімізацією персональних даних, що має неабияке значення для сфери відносин щодо створення та використання біобанків, пропонуємо доповнити визначення персональних даних у ст. 2 Закону України «Про захист персональних даних», виклавши його в такій редакції: «Персональні дані - відомості чи сукупність відомостей про фізичну особу, яка ідентифікована або може бути конкретно ідентифікована, в тому числі закодовані персональні дані, які можуть бути розкодовані». Таке формулювання поняття персональних даних виключить можливість винесення за межі сфери застосування даного закону закодовані персональні дані, що створить додаткові гарантії для захисту таких персональних даних та відповідатиме вимогам нового Регламенту EC $2016 / 679$.

\section{Jimepamypa}

1. Закон України «Про захист персональних даних» від 01.06.2010 року № 2297-VI. URL : https://zakon.rada.gov.ua/laws/show/2297-17.

2. Закон України «Про інформацію» від 02.10 .1992 року № 2657-XII. URL : https://zakon.rada.gov.ua/laws/show/2657-12.

3. Закон України «Про доступ до публічної інформації» від 01.05.2015 року № 2939-VI. URL : https://zakon.rada.gov.ua/laws/show/2939-17.

4. Терзі О.О. Правове регулювання предиктивної медицини. Альманах права. 2017. № 8. URL : http://nbuv.gov.ua/UJRN/ap_2017_8_98.

5. Культенко О.В. Про необхідність законодавчого схвалення концепції проведення молекулярно-генетичної експертизи в Україні. Держава і право. Юридичні і політичні науки. 2014. Вип. 66. C. $246-254$.

6. Fernandes M.S., Ashton-Prolla P., Stoll de Moraes L., Matte U.S. et al. Genetic information and biobanking: a Brazilian perspective on biological and biographical issues. URL : http://www.nncbi.nlm.nih.gov/pmc/articles/PMC4524876/.

7. Regulation (EU) 2016/679 of the European Parliament and of the Council of 27 April 2016 on the protection of natural persons with regard to the processing of personal data and on the free movement of such data and repealing Directive 95/46/EC. URL : http://eur-lex.europa.eu/legal-content/en/ $\mathrm{TXT} /$ ?uri=CELEX $\% 3$. 
8. Основи законодавства України про охорону здоров'я від 19.11 .1992 р. Відомості Верховної Ради України. 1993. № 4. Ст. 19.

9. Омельченко О. Захист біобанками персональних даних донорів у контексті принципу відкритості науки. Підприємниитво, господарство і право. 2017. № 12. С. 54-57.

10. Закон України від 17.05.2018 № 2427-VIII «Про застосування трансплантації анатомічних матеріалів людині». URL : https://zakon.rada.gov.ua/laws/show/2427-19.

\section{Анотація}

Квіт Н. М. Право на захист персональних і генетичних даних - один із аспектів правового статусу донора як суб’єкта відносин зі створення та використання біобанку. - Стаття.

Стаття присвячена висвітленню проблем захисту персональних, у тому числі особливо чутливих генетичних даних особи, яка передає свої біологічні матеріали та пов'язану із ними інформацію до складу біобанку на засадах донорства. Розглядається поняттєвий апарат чинного законодавства у цій сфері, зокрема проаналізовано законодавче визначення персональних даних, конфіденційної інформації, а також генетичних даних. Показано наявні на практиці ризики та загрози для особистих немайнових прав донорів, у тому числі права на захист їх персональних, генетичних даних. Зроблено наголос на тому, що інформація, яка передається до складу біобанку донором разом із біологічним матеріалом, також підпадає під охорону особистого немайнового права фізичної особи на таємницю про стан ії здоров'я. Проаналізовано встановлені в Регламенті ЄС вимоги щодо забезпечення охорони персональних даних, які співставлені із чинним національним законодавством. Констатовано повну відповідність деяких положень закону про захист персональних даних нормам вимогам європейського законодавства. Проте також встановлено, що деякі норми чинного законодавства формують сприятливі умови для зловживань у сфері використання генетичних даних, констатовано недостатню увагу українського законодавця до визначення таких способів захисту персональних даних, як їх анонімізація та псевдонімізація. У зв'язку із цим проведено розмежування даних понять та запропоновано вдосконалене визначення персональних даних, що усуне існуючу прогалину. Крім того, зроблено висновок про необхідність спеціального правового регулювання охорони персональних даних особи, пов'язаних зі ії здоров'ям, у тому числі генетичних даних у контексті відносин щодо створення та використання біобанків та формування спільних баз таких даних в Україні. А також констатовано необхідність встановлення законодавчих вимог щодо передачі таких даних, щодо форми та змісту згоди особи та правових наслідків порушення таких вимог.

Ключові слова: персональні дані, генетичні дані, анонімізація, псевдонімізація, донор, біобанк.

\section{Summary}

Kvit N.M. The right to the protection of personal and genetic data - one of the aspects of the legal status of the donor, as the subject of relations for the creation and use of the biobank. - Article.

This article deals with the problems of protection of personal, including especially sensitive genetic data of the persons who transmits their biological materials and related information to the biobank on the basis of donation. The conceptual apparatus of the current legislation in this field is considered, in particular the legislative definition of personal data, confidential information, as well as genetic data is analyzed. The practical risks and threats to donors' personal non-property rights, including the rights to protect their personal, genetic data, are outlined. It is also emphasized, that information transmitted to the biobank by the donor, together with biological material, also falls under the protection of the individual's personal non-property right to secrecy about his or her health status. The requirements set out in the EU Regulation for the protection of personal data, which are compared with the current national legislation, are analyzed. Some provisions of the law on protection of personal data have been fully complied with the rules and requirements of the European legislation. However, it has also been found that some provisions of the current legislation create favorable conditions for the abuse of genetic data and that the Ukrainian legislature is insufficient to identify ways of protecting personal data as anonymization and pseudonymisation. This is why they differentiate between these concepts and provide an improved definition of personal data that will eliminate the existing gap. In addition, it was concluded that there is a need for special legal regulation of the protection of a person's personal data related to his or her health, including genetic data in the context of relationships regarding the creation and use of biobanks and the creation of common databases of such data in Ukraine. It was also stated the need to establish legal requirements for the transmission of such data, the form and content of the person's consent and the legal consequences of violating such requirements.

Key words: personal data, genetic data, anonymization, pseudonymisation, donor, biobank. 